\title{
Chronobiologic blood pressure assessment: Maturation of the daily rhythm in newborn foals
}

\author{
GIUSEPPE PICCIONE, ANNA ASSENZA, FRANCESCO FAZIO, \\ CLAUDIA GIANNETTO and GIOVANNI CAOLA
}

\begin{abstract}
Dipartimento di Scienze Sperimentali e Biotecnologie Applicate, Laboratorio di Cronofisiologia Veterinaria, Facoltà di Medicina Veterinaria, Università degli Studi di Messina, Polo Universitario dell'Annunziata, Messina, Italy
\end{abstract}

\begin{abstract}
Circadian rhythmicity of physiological processes in animals has been described for some variables. In order to investigate the daily rhythmicity of blood pressure, seven foals (Equus caballus) were used for 40 days after birth. Measurements of blood pressure were done by means of an oscillometric apparatus (Argus TM-7, Schiller, Barr Switzerland) with the foals in a standing position and the cuff placed around the tail. Blood pressure was recorded twice a day, 1 hour before dawn and 1 hour before dusk for the first 10 days of life, every 2 days from the $11^{\text {th }}$ to the $32^{\text {nd }}$ day, on the $36^{\text {th }}$ and on the $40^{\text {th }}$ day. Two-way repeated measures analysis of variance (ANOVA) were used to determine statistically significant differences between the mean values recorded at dawn and dusk during the study. Analysis of variance showed a significant effect of time $(\mathrm{p}<0.0001)$, during the first 40 days of life. This study confirms a strong correlation between age and blood pressure in horse and the absence of blood pressure maturation in foals 40 days old. The results on the maturation of the daily rhythm of blood pressure in foals is a contribution to the study of the development of circadian rhythms in mammals. These results are also useful for the chronophysiological assessment of blood pressure in the horse.
\end{abstract}

Key terms: blood pressure, circadian rhythm, chronophisiology, foals, Equus caballus.

\section{INTRODUCTION}

Circadian rhythmicity in physiological processes in animals has been described for a multitude of variables (Piccione and Caola, 2002; Dunlap et al., 2004; Refinetti, 2005). Daily rhythmicity is generated by a circadian pacemaker located in the suprachiasmatic nucleus of the hypothalamus, which is modulated by environmental cycles of light and darkness, food availability, ambient temperature, and other factors (Van Esseveldt et al., 2000; Helfrich-Förster, 2004). Circadian rhythmicity implies that under constant external condition (without time cues) the rhythms free-run with an endogenous period are close but not identical to $24 \mathrm{~h}$.
Several physiologic rhythms, including those of the cardiovascular system, react to both endogenous and exogenous influences (Guo and Stein, 2003). As many other physiological functions, blood pressure shows significant temporal variations. The large extent of spontaneous change within the physiologic range of blood pressure can be resolved and should be exploited. In man, it is well known that there is a gradual rise of blood pressure (Comstock, 1957; Eilertsen and Humerfelt, 1968; Hamilton et al., 1954); it is evident that heart rate variability, as well as effects of blood pressure variability, seem to be influenced by age, health status, and nutritional factors (Singh et al., 2003). It is possible to predict this variability, since it shows a rhythmic pattern.

Corresponding Author: Prof. Giuseppe Piccione, Dipartimento di Scienze sperimentali e Biotecnologie applicate, Laboratorio di Cronofisiologia Veterinaria, Facoltà di Medicina Veterinaria, Università di Messina Polo Universitario dell'Annunziata, 98168 Messina, Italy; Tel: +390903503584; Fax: +390903503975 ; E-mail: giuseppe.piccione@unime.it 
Among the temporal rhythms, circadian progress mainly is characterized by systolic and diastolic pressure. A circadian rhythm in blood pressure has been demonstrated in various species of mammals, including rat (Van Den Buuse, 1994; Sato et al., 1995), rabbit (Sato et al., 1995), cat (Brown et al., 1997), dog (Mishina et al., 1999; Piccione et al., 2005a), cattle (Fazio et al., 2002), marmoset (Schnell and Wood, 1993) and mouse (Gross et al., 2000). Many reseachers have reported that cardiovascular indices, like sympathetic activity increase significantly during the day and decrease during the night; parasympathetic activity does the opposite (Veerman et al., 1995). Circadian blood pressure rises at night in rats, which are nocturnal (Baumgart, 1991; Buuse, 1994; Conway et al., 1983; Friberg et al., 1989; Ittersun et al., 1995; Kawano et al., 1994; Mancia et al., 1993). Some studies, carried out on dogs, reported low mean BP throughout the night to early morning and high BP from early morning and throughout the day (Broten et al., 1988). Other authors (Mishina et al., 1999) have monitored the 24-h BP in dogs using telemetry and observed changes almost identical to those reported in humans (Baumgart, 1991; Mancia et al., 1993; Sundberg et al., 1988) with the highest values during periods of activity and the lowest during sleep.

Rhythmic variations at different frequencies both for systolic and diastolic pressure and heart rate were recorded only in athletic horse (Piccione et al., 2001). Measurements of the blood pressure have been obtained in horse and foals from different authors (Ostlund et al., 1983; Franco et al., 1986), but no circadian rhythmicity was assessed. Furthermore, during the neonatal period, homeostatic mechanisms complete their maturation, thereby allowing the foal's adaptation to extra-uterine life (Piccione et al., 2002). In horse, the fetal maturation that makes the passage to extra-uterine life possible begins only during the last 5 days of pregnancy and ends within the first 7-10 days of life (Le Blanc, 1996; Bucca, 2001). Because of the lack of data on the cardiovascular chronophysiology in domestic species, especially in horse, the aim of our research is to define the temporal organization of the cardiovascular system, taking into particular consideration the circadian pattern of blood pressure and the maturation of the daily rhythm in newborn foals.

\section{METHODS}

\section{Animals}

Seven Thoroughbred foals (Equus caballus) (mean body weight $50 \mathrm{~kg}$ ) were used for 40 days after birth. Mother's milk was the only source of food for the foals. Each foal was maintained in a separate indoor stall. Horses were kept under natural photoperiod and natural indoor temperature. The study was conducted in the early spring in Sicily, when the photoperiod consists of 11-12 h of sunlight per day, and the average indoor temperature is $19^{\circ} \mathrm{C}$.

\section{Procedure}

Recordings of blood pressure were done by means of an oscillometric apparatus (Argus TM-7, Schiller, Barr Switzerland) with the foal minimally restrained in a standing position. The blood pressure obtained can be corrected to the heart base level. A pneumatic rubber cuff was placed around the base of the tail, and the transducer part of the flow detector was centred squarely over the middle coccygeal artery at the base of the tail. The cuff was secured snugly, as close to the body as possible, using the Velcro self-adhesive cloth sleeve covering the cuff. Any hair interfering with a good connection between the transducer and the skin was removed. The cuff was automatically inflated and deflated at regular predetermined intervals. Blood pressure was recorded from each animal twice a day, 1 hour before dawn (07: 00) and 1 hour before dusk (17:00) for the first 10 days of life, every 2 days from the $11^{\text {th }}$ to the $32^{\text {nd }}$ day, on the $36^{\text {th }}$ and on the $40^{\text {th }}$ day.

Blood pressure reflects the activation of the adrenergic system and the adrenal 
cortex preparing for the start of the day's motor activity (Cornélissen et al., 1994). These times were chosen because they correspond to the trough and peak, respectively, of the daily rhythm of motor activity in mammals maintained under a photoperiod with $12 \mathrm{~h}$ of light per day (Refinetti, 1999). Blood pressure values (systolic and diastolic) were not recorded until three measurements could be taken at 15 min intervals without varying more than 10-15 mmHg. Mean arterial blood pressure was obtained directly from the oscillometric apparatus. Feeding never preceded the measurement of blood pressure by less than $4 \mathrm{~h}$.

All work presented here complies with current regulations covering animal experimentation in Italy. The results are expressed in mean \pm SEM. Two-way repeated measures analysis of variance (ANOVA) were used to determine statistical significant differences between the mean values recorded at dawn and dusk during the study. Main effects associated with probalities equal to or lower than 0.05 were considered statistically significant.

\section{RESULTS}

Figure 1 shows the pattern of systolic and diastolic blood pressure in foals. The twoway ANOVA showed statistically significant effects of time, during the first 40 days of life, as follow: systolic pressure $\mathrm{F}_{(23, .276)}=12.03, \mathrm{p}<0.0001$, diastolic pressure $\mathrm{F}_{(23,276)}=11.46, \mathrm{p}<0.0001$, mean blood pressure $\mathrm{F}_{(23,276)}=1.58, \mathrm{p} \leq 0.047$. It no showed a statistical significant difference between dawn and dusk: systolic pressure $\mathrm{F}_{(1,276)}=3.04, \mathrm{p}=0.10$, diastolic pressure $\mathrm{F}_{(1,276)}=4.59, \mathrm{p}=0.053$, mean blood pressure $\mathrm{F}_{(1,276)}=0.18, \mathrm{p}=0.67$. Systolic pressure decreased 1 hour before dawn from $156.50 \pm 2.18 \mathrm{mmHg}\left(1^{\text {st }}\right.$ day of life) to $144.10 \pm 1.83 \mathrm{mmHg}\left(40^{\text {th }}\right.$ day of life); diastolic pressure decreased from $81.83 \pm 1.77 \mathrm{mmHg}\left(1^{\text {st }}\right.$ day of life) to $73.00 \pm 1.15 \mathrm{mmHg}\left(40^{\text {th }}\right.$ day of life $)$; mean pressure decreased from $105.00 \pm 1.82$ $\mathrm{mmHg}\left(1^{\text {st }}\right.$ day of life $)$ to $96.72 \pm 1.32$ $\mathrm{mmHg}\left(40^{\text {th }}\right.$ day of life). Pressure measured
1 hour before dusk changed as follow: systolic pressure from $157.30 \pm 2.51 \mathrm{mmHg}$ ( $1^{\text {st }}$ day of life) to $143.67 \pm 1.78 \mathrm{mmHg}$ (40 ${ }^{\text {th }}$ day of life), diastolic pressure from $82.16 \pm 0.94 \mathrm{mmHg}$ ( $1^{\text {st }}$ day of life) to $73.00 \pm 1.52 \mathrm{mmHg}\left(40^{\text {th }}\right.$ day of life $)$; mean pressure from $107.00 \pm 1.11 \mathrm{mmHg}\left(1^{\text {st }}\right.$ day of life) to $96.56 \pm 1.36 \mathrm{mmHg}$ (40 th day of life). By the $33^{\text {rd }}$ day of life, the difference of systolic pressure recorded between the dawn and dusk was approximately 1.50 $\mathrm{mmHg}$, except a the $5^{\text {th }}$ and $10^{\text {th }}$ day after birth; diastolic pressure was approximately $0.80 \mathrm{mmHg}$, except on the $5^{\text {th }}-6^{\text {th }}$ day and $9^{\text {th }}-10^{\text {th }}$ day after birth.

\section{DISCUSSION}

Our results show the absence of a circadian rhythmicity of blood pressure in up to foals 40 days old, contrary finding for body temperature in sheep and horse, in which a body temperature rhythm similar to that of adults is achieved approximately 10 days after birth and fully matures during the first month of life (Piccione et al., 2002). As showed by other authors (Covington and McNutt, 1931; Ostlund et al., 1983), our study confirms a strong correlation between age and blood pressure in horse.

During the $1^{\text {st }}$ day of life, mean blood pressure had a value of $105.00 \pm 1.82$ $\mathrm{mmHg}$ at dawn and $107.00 \pm 1.11 \mathrm{mmHg}$ at dusk, which is also consistent with previous observations (Drummond, 1990). This high value recorded following the post-partum period is due to the highest activity of the RAA (Renin-Angiotensin-Aldosterone) system during pregnancy, fetal and neonatal life (Guignard, 1982; Carr and Gant, 1983; Pipkin, 1984). Towards term in the horse fetus, the increase in arterial blood pressure occurs together with reductions in metatarsal vascular resistance, elevations in plasma concentrations of cortisol, vasopressin, and noradrenaline and falls in the fetal/maternal ratio of blood $\mathrm{PO}_{2}$ (Giussani et al., 2005). Once the lung expands and $\mathrm{PO}_{2}$ increases pulmonary blood flow increases ten-fold. Meanwhile, the placental circulation is eliminated, converting the systemic circulation from a 

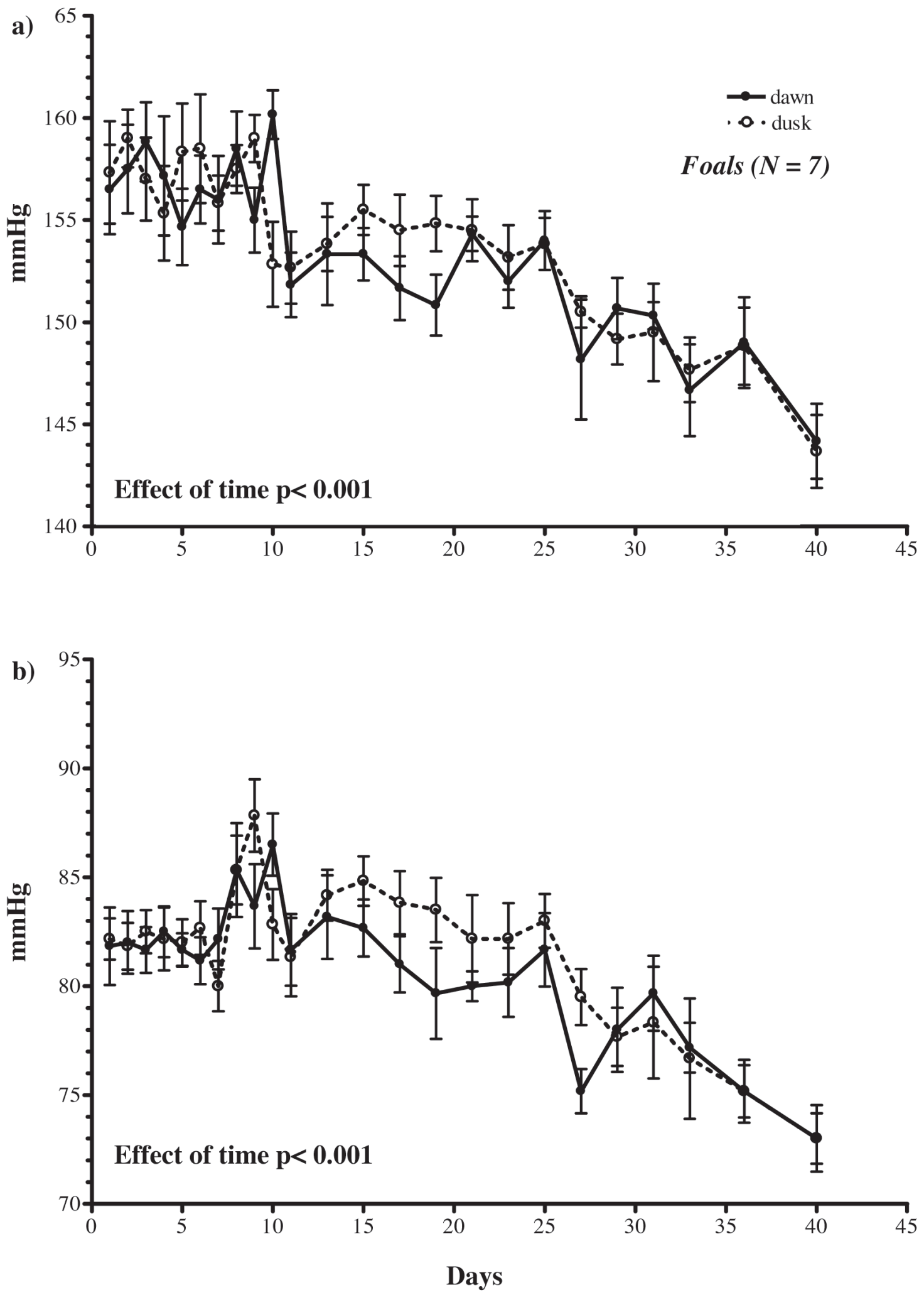

Figure 1. Blood pressure (a: systolic; b: diastolic) of newborn foals recorded 1 hour before dawn and 1 hour before dusk for 40 days after birth. Symbols are means of the number of animals indicated, and the error bars indicate the standard errors of the means. 


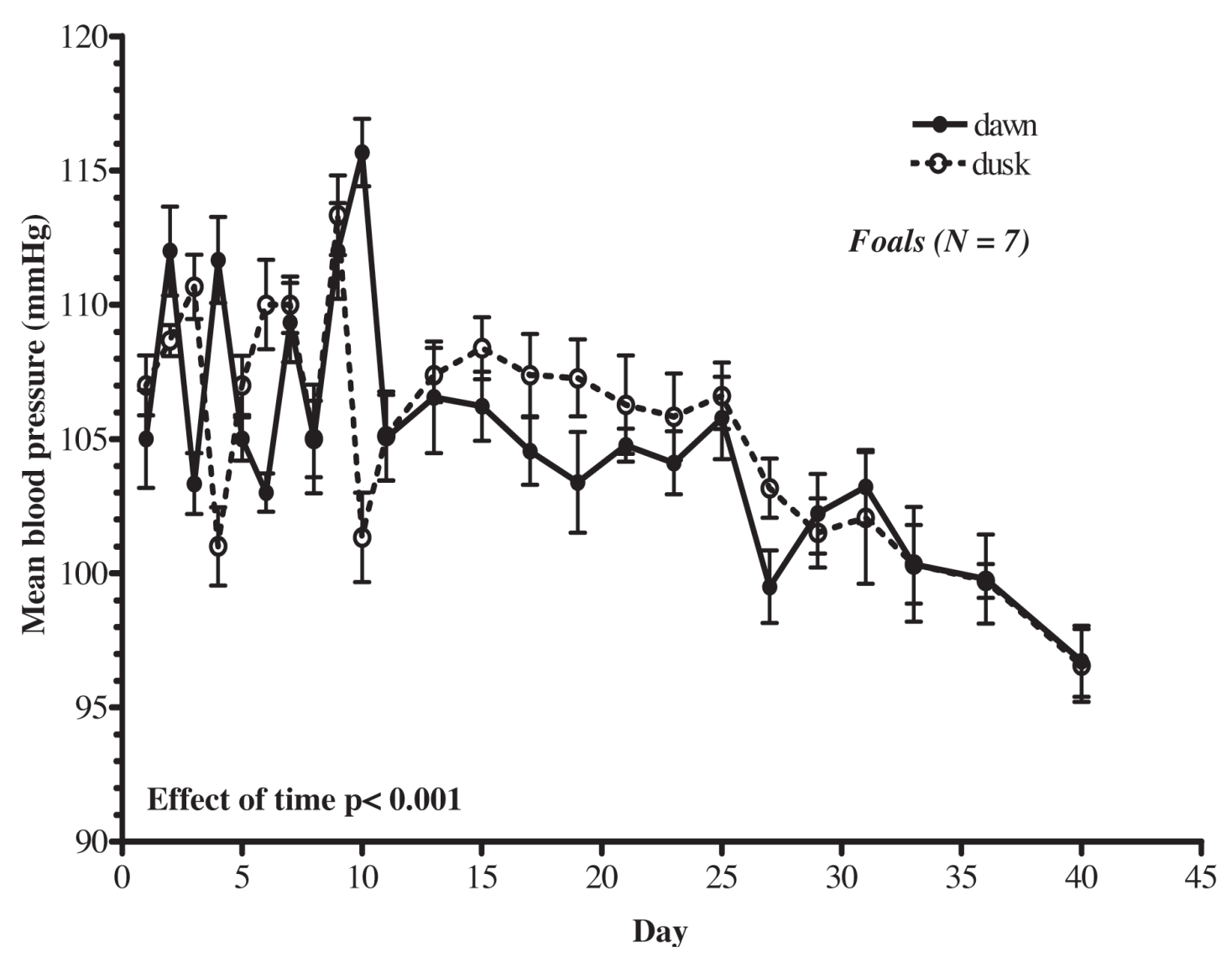

Figure 2: Blood pressure (a: systolic; b: diastolic) of mares recorded one hour before dusk and one hour before dawn for 40 days after parturition. Symbols are means of the number of animals indicated and the error bars indicate the standard errors of the means.

low-resistance system to a high-resistance system (Lombard, 1990). The foals' mean blood pressure 40 days after the birth was approximately $5 \mathrm{mmHg}$ higher than that of one adults (Drummond, 1990), because of the immaturity of autonomic nervous function, as in children (Massin et al., 2000) and calves (Fazio et al., 2002).

The circadian rhythm of blood pressure is widely affected by the activity of the autonomic nervous system and by circadian fluctuations of the following systems: endogenous oppioids, hypothalamushypophysis axis, renin-angiotensinaldosterone complex, renal function and vasoactive peptides (Portaluppi et al., 1990; $1992 ; 1993 a ; 1993 b ; 1996)$. The activity of the renin-angiotensin system also has a circadian rhythm, with a diurnal acrophase, as widely showed in laboratory animals
(Lemmeer et al., 2000), and the pattern of its circadian rhythm coincides with the circadian pattern of heart rate and blood pressure, which also demonstrates diurnal acrophase (Kawasaki et al., 1983; Cugini et al., 1985). Ten-day-old lamb and foal both show a circadian rhythm of body temperature. This rhythmicity is lacking in blood pressure, as previously observed for heart rate and respiratory rate (Piccione et al., 2005b), may be caused by different control systems, and probably correlates with the incomplete anatomical-functional development of the cardiovascular system.

Blood pressure can be considered not only as part of the maturation process, but may be also connected with the horse's age (Ostlund et al., 1983). The results on the maturation of the daily rhythm of blood pressure in foals are a contribution to the 
study of the development of circadian rhythms in mammals. These results are also useful for the chronophysiological assessment of blood pressure in the horse and for pharmacological applications.

The rise in blood pressure showed in horse and linked to the animal's age, probably starts after the maturation period, in which it is possible observed the opposite phenomenon, that is, a gradual decrease of blood pressure from birth to about 40 days of life. This can be considered part of the aging process or as a common phenomenon among mammals. The absence of a daily rhythmicity of blood pressure in foals to 40 day after birth could be due to the incomplete maturation of endogenous process, thus further studies are needed in order to define the maturation of the cyclic rhythm of blood pressure.

\section{REFERENCES}

BAUMGART P (1991) Circadian rhythm of blood pressure: Internal and external time triggers. Chronobiol Int 8: 444-450

BROTEN TP, ZEHR JE, LIVNAT A (1988) Statistical criteria for using short-term measurements as an index of 24-h mean arterial pressure in unanesthetized unrestrained dogs. Life Science 42: 1625-1633

BROWN SA, LANGFORD K, TARVER S (1997) Effects of certain vasoactive agents on the long-term pattern of blood pressure, heart rate, and motor activity in cats. Am J Vet Res 58: 647-652

BUCCA S (2001) Valutazione e gestione del neonato equino a rischio. Riv Ippiat E Ippol 7: 7-31

BUUSE MVD (1994) Circadian rhythms of blood pressure, heart rate, and locomotor activity in spontaneously hypertensive rats as measured with radio-telemetry. Physiol Behav 55: 783-787

CARR BR, GANT NF (1983) The endocrinology of pregnancy-induced hypertension. Review Clin Perinatol 10: 737-761

COMSTOCK GW (1957) An epidemiological study of blood pressure levels in a biradical community in the southern United States. Am J Hyg 65: 271-315

CONWAY J, BOON N, JONES J, SLEIGHT P (1983) Involvement of the baroreceptor reflex in the changes in blood pressure with sleep and mental arousal. Hypertension 5: 746-748

CORN LISSEN G, HAUS E, HALBERG F (1994) Chronobiologic blood pressure assessment from womb to tomb. In: TOUITOU Y, HAUS E (eds) Biologic rhythms in clinical and laboratory medicine. Berlin: Springer-Verlag. pp: 428-452

COVINGTON NG, MCNUTT GW (1931) Studies of normal blood pressure in animals. Blood pressure in the horse with a brief note of the ox. J Am Vet Med Ass 79: 603-624

CUGINI P, HALBERG F, SOTHERN RB, ET AL. (1985) Sodium restriction amplifies and propranolol inhibits circadian rhythm of plasma rennin-angiotensin and aldosterone. Chronobiologia 12: 155-65

DUNLAP JC, LOROS JJ, DECOURSEY PJ (2004) Chronobiology: Biological timekeeping. Sunderland, MA: Sinaur Associates

DRUMMOND WH (1990) Neonatal shock: Pathophysiology and management. In: KOTERBA AM, DRUMMOND WH, KOSCH PC (eds) Equine clinical neonatology. Philadelphia: Lea and Febiger. pp: 106123

EILERTSEN E, HUMERFELT S (1968) The blood in a representative population sample. Acta Med Scand 183: 293-305

FAZIO F, GRASSO F, NICOSIA S, PERCIPALLE M (2002) Blood pressure rhythmic pattern in cattle. Proceedings of the symposium "Biological rhythms in livestock" Messina, Italy pp: 100-108

FRANCO RM, JENNY C, CASH RSG, ROSSDALE PD (1986) Study of arterial blood pressure in newborn foals using an electronic sphygmomanometer. Equine Vet J 18: 475-478

FRIBERG P, KARLSSON B, NORDLANDER M (1989) Autonomic control of the diurnal variation in arterial blood pressure and heart rate in spontaneously hypertensive and Wistar-Kyoto rats. J Hypertens 7: 799-807

GIUSSANI DA, FORHEAD AJ, FOWDEN AL (2005) Development of cardiovascular function in the horse fetus. J Physiol 15: 1019-30

GROSS V, MILIA AF, PLEHM R, INAGAMI T, LUFT FC (2000) Long-term blood pressure telemetry in AT2 receptor-disrupted mice. J Hypertens 18: 955-961

GUIGNARD JP (1982) Renal function in the newborn infant. Pediatr Clin North Am 29: 777-790

GUO YF, STEIN PK (2003) Circadian rhythm in the cardiovascular system. Chronocardiology Am Heart J 145: $779-86$

HAMILTON MJ, PICKERING GV, FRASER ROBERTS JA, SOWRY GSC (1954) The aetiology of essential hypertension-1. The arterial pressure in the general population. Clin Sci 13: 273-304

HELFRICH-FÖRSTER C (2004) The circadian clock in the brain: a structural and functional comparison between mammals-and insects. J Comp Physiol A 190: 601-613

KAWANO Y, TOCHIKUBO O, MINAMISAWA K, MIYAJIMA E, ISHII M (1994) Circadian variation of haemodynamics in patients with essential hypertension: Comparison between early morning and evening. J Hypertens 12: 1405-1412

KAWASAKI T, UEZONO $\mathrm{K}$, UENO $\mathrm{M}$, OMAE $\mathrm{T}$, MATSUOKA M, HAUS E, HALBERG F (1983) Comparison of circadian rhythms of the reninangiotensin-aldosterone system and electrolytes in clinically healthy young women in Fukuoka (Japan) and Minnesota (USA). Acta Endocrinologica 102: 246-51

ITTERSUN FJ, IJZERMAN RG, STEHOUWER CDA, DONKER AJM (1995). Analysis of 24-h ambulatory blood pressure monitoring: What time period to assess blood pressures during waking and sleeping? J Hypertens 13: 1053-1058

LE BLANC MM (1996) Equine perinatology: What we known and what we need to know Animal Reprod Scien 42: 189-196

LEEMER B, WITTE K, SCHÄNZER A, FINEDEISEN A (2000) Circadian rhythms in the rennin-angiotensin system and adrenal steroids may contribute to the inverse blood pressure rhythm in hypertensive TGR (mREN-2)27 rats. Chronobiol Int 17: 645-658

LOMBARD CW (1990) Cardiovascular disease. In: KOTERBA AM, DRUMMOND WH, KOSCH PC (eds) 
Equine clinical neonatology. Philadelphia: Lea and Febiger. pp: 240-261

MANCIA G, FERRARI A, GREGORINI L, PARATI G, POMIDOSSI G, BERTINIERI G, GRASSI G, RIENZO M, PEDOTTI A, ZANCHETTI A (1993) Blood pressure and heart rate variabilities in normotensive and hypertensive human beings. Circadian Res 53: 96104

MASSIN MM, MAEYNS K, WITHOFS N, RAVET F, GERARD P (2000) Circadian rhythm of heart rate and heart rate variability. Arch Dis Child 83: 179-82

MISHINA M, WATANABE T, MATSUOKA S, SHIBATA K, FUJII K, MAEDA H WAKAO Y (1999) Diurnal variations of blood pressure in dogs. J Vet Med Sci 61: 643-647

OSTLUND C, PERO RW OLSSON B (1983) Reproducibility and the influence of age on interspecimen determinations of blood pressure in the horse. Comp Biochem Physiol 74A: 11-20

PICCIONE G, ASSENZA A, ATTANZIO G, FAZIO F, CAOLA G (2001) Chronophysiology of arterial blood pressure and heart rate in athletic horses. Slov Vet Res 38: $243-248$

PICCIONE G, CAOLA G (2002) Biological rhythm in livestock. J Vet Sci 3: 145-157

PICCIONE G, CAOLA G, REFINETTI R (2002) Maturation of the daily body temperature rhythm in sheep and horse. J Thermal Biology 27: 333-336

PICCIONE G, ASSENZA A, COSTA A, BORRUSO M, FAZIO F, CAOLA G (2005a) Monitoring of some physiological parameters during the first 30 days of a foal's life. Medycyna Wet 61: 1142-1144

PICCIONE G, CAOLA G, REFINETTI R (2005b) Daily rhythms of blood pressure, heart rate, and body temperature in fed and fasted male dogs. J Vet Med A 52: $377-381$

PIPKIN FB (1984) The renin-angiotensin system in mother and foetus. Equine Vet J 16: 253-255

PORTALUPPI F, BAGNI B, DEGLI UBERTI E, MONTANARI L, CAVALLINI R, TRASFERINI G, MARGUTTI A, FERLINI M, ZANELLA M, PARTI M (1990) Circadian rhythms of arterial natiuretic peptide, renin, aldosterone, cortisol, blood pressure and heart rate in normal and hypertensive subjects. J Hypertens 8: $85-95$

PORTALUPPI F, TRASFERINI G, MARGUTTI A, VERGNANI L, AMBROSIO MR, ROSSI R, BAGNI B, PANSINI R, DEGLI UBERTI E (1992) Circadian rhythm of calcitonin gene-related peptide in uncomplicated essential hypertension. J Hypertens 10: $1227-1234$
PORTALUPPI F, VERGNANI L, DEGLI UBERTI E (1993a) Arterial natriuretic peptide and circadian blood pressure regulation: clues from a chronobiological approach. Chronobiol Int 10: 176-189

PORTALUPPI F, VERGNANI L, MARGUTTI A, AMBROSIO MR, BONDANELLI M, TRASFERINI G, ROSSI R, DEGLI UBERTI E (1993b) Modulatory effect of the renin- angiotensin system on the plasma levels of calcitonin gene-related peptide in normal man. J Clin Endocrinol Metab 77: 816-820

PORTALUPPI F, VERGNANI L, MANFREDINI R, FERSINIO C (1996) Endocrine mechanisms of blood pressare rhythms. Annals of NY Academic Sciences 783: 113-131

REFINETTI R (1999) Relationship between the daily rhythms of locomotor activity and body temperature in eight mammalian species. Am J Physiol 277: R1493R1500

REFINETTI R (2005) Circadian physiology. 2nd ed. Boca Raton FL: CRC Press

SATO K, CHATANI F, SATO S (1995) Circadian and short-term variabilities in blood pressure and heart rate measured by telemetry in rabbits and rats. Journal of the Autonomic Nervous System 54: 235-246

SCHNELL CR, WOOD JM (1993) Measurement of blood pressure and heart rate by telemetry in conscious, unrestrained marmosets. Am J Physiol 33: H1509H1516

SINGH RB, CORNE’LISSEN G, WEYDAHLC A, SCHWARTZKOPFF O, KATINAS G, OTSUKA K, WATANABE Y, YANO S, MORI-H, ICHIMARU-Y, MITSUTAKE G, PELLA D, FANGHONG L, ZHAO Z, RAO RS, GVOZDJAKOVA A, HALBERG F (2003) Circadian heart rate-and blood pressure variability considered for-research-and patient care. Int J Cardiol 87: 9-28

SUNDBERG S, KOHVAKKA A, GORDIN A (1988) Rapid reversal of circadian blood pressure rhythm in shift workers. J Hypertens 6: 393-396

VAN DEN BUUSE M (1994) Circadian rhythms of blood pressure, heart rate, and locomotor activity in spontaneously hypertensive rats as measured with radio-telemetry. Physiol Behav 55: 783-787

VAN ESSEVELDT LE, KEHMAN MN, BOER GJ (2000) The suprachiasmatic nucleus and the circadian timekeeping system revisited. Brain Res 33: 34-77

VEERMAN DP, IMHOLZ BPM, WIELING W, WESSELING KH, VAN MONTFRANS GA (1995) Circadian profile of systemic hemodynamics. Hypertens 26: 55-59 
